
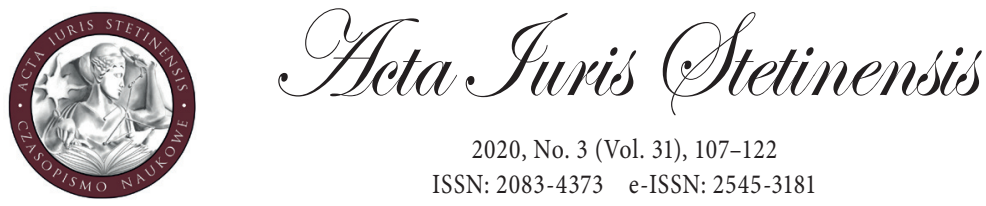

2020, No. 3 (Vol. 31), 107-122

ISSN: 2083-4373 e-ISSN: 2545-3181

DOI: $10.18276 /$ ais.2020.31-07

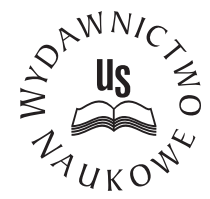

Monika Smusz-Kulesza

Ph.D.

University of Lodz, Poland

e-mail: mkulesza@wpia.uni.lodz.pl

OPEN ACCESS

ORCID ID: 0000-0001-7392-4464

\title{
Protection of the rights of persons with disabilities under the European Social Charter
}

\begin{abstract}
The aim of the study is to discuss the protection of the rights of persons with disabilities under the system of law of the Council of Europe. In particular, the focus is on the rights of persons with disabilities to independence, social integration, and participation in the life of the community under the European Social Charter (ESC). This paper covers both an analysis of the Charter, with special attention paid to Article 15, and an examination of the decisions of the European Committee of Social Rights (ECSR) with respect to this provision. Besides the regulation of these rights at the European level, this paper also discusses different examples of state regulations' conformity or non-conformity with Article 15 ESC.
\end{abstract}

Keywords: rights of people with disabilities, social rights, human rights, European Social Charter, protection of social rights

\section{Introduction}

The Council of Europe is the leading human rights organisation in Europe whose stated aim is to uphold human rights, democracy, and the rule of law in Europe. It 
includes 47 member states ${ }^{1}$ and covers about 820 million people. ${ }^{2}$ The European Social Charter (ESC) is a Council of Europe treaty that guarantees fundamental social and economic rights related to employment, housing, health, education, social protection, and welfare. ${ }^{3}$ The Charter is intended to be the counterpart ${ }^{4}$ in the field of economic and social rights to the 1950 European Convention on Human Rights (ECHR), the major achievement of the Council of Europe in the field of human rights. ${ }^{5}$

The ESC has two versions, the first signed in 1961 and the second signed in 1996. The 1996 Charter is an extended revision of the 1961 one. The 1961 Charter $^{6}$ first recognised a list of social rights related to work, social protection, and vulnerable groups of people, as well as a reporting system as a mandatory monitoring mechanism. ${ }^{7}$ Later, the Charter of 1961 was expanded and amended to include a series of instruments. The final result of the process was the adoption in 1996 of the European Social Charter (Revised), ${ }^{8}$ which entered into force on 1 July 1999. This Revised Charter was basically intended to update and adapt the substantive content of the original Charter and supplement its provisions in light of the social changes and developments since the adoption of the original text. Today, the Charter treaty system is one of the most widely accepted sets of human rights standards

1 Members of the Council of Europe are: Albania, Andorra, Armenia, Austria, Azerbaijan, Belgium, Bosnia and Herzegovina, Bulgaria, Croatia, Cyprus, Czech Republic, Denmark, Estonia, Finland, France, Georgia, Germany, Greece, Hungary, Iceland, Ireland, Italy, Latvia, Liechtenstein, Lithuania, Luxembourg, Malta, Monaco, Montenegro, Netherlands, North Macedonia, Norway, Poland, Portugal, Republic of Moldova, Romania, Russian Federation, San Marino, Serbia, Slovak Republic, Slovenia, Spain, Sweden, Switzerland, Turkey, Ukraine and the United Kingdom.

2 https://www.coe.int/en/web/about-us/budget (accessed 15.02.2020).

3 For an excellent if by now outdated overview of the ESC, see: Harris, D. and D'Arcy, J., The European Social Charter, 2nd edition, Ardsley 2001. See also the collected essays in: De Schutter, O. (ed.), The European Social Charter: A social constitution for Europe, Bruylant 2010.

4 See more: O'Cinneide, C., The European Social Charter and the UK: why it matters, "King's Law Journal" 2018, Vol. 29, No. 2, pp. 275-296.

5 Stein, E., The European Social Charter-instruments and procedures, "Nordic Journal of Human Rights", Vol. 25, No. 1, 2007, pp. 58-64.

6 CoE, European Social Charter, ETS No. 35, opened for signature in Turin on 18 October 1961, in force since 26 February 1965.

7 For early comments, see : Harris, D., The European Social Charter, "International and Comparative Law Quarterly" 1964, Vol. 13, pp. 1076-1087; Valticos, N., La Charte sociale européenne: sa structure, son contenu, le contrôle de son application, "Droit Social" 1963, Vol. 26, pp. 466-482; Wiebringhaus, H., La Charte sociale européenne, "Annuaire Français de Droit International" 1963, Vol. 9, pp. 709-721.

8 CoE, European Social Charter (Revised), CETS No. 163, opened for signature in Strasbourg on 3 May 1996, in force since 1 July 1999. 
within the Council of Europe. The widespread support for social rights is ensured by the fact that 43 out of the 47 member states of the Council of Europe are parties to either the 1961 Charter or the 1996 Revised Charter. ${ }^{9}$ Poland is a party to the 1961 Charter. It signed, but has not yet ratified, the 1996 Revised Charter.

In terms of structure, the 1961 Charter and the 1996 Revised Charter are similar. The rights protected are listed in general terms in Part I, which contains a policy commitment that is not legally binding. In Part II, the rights are specified and made the subject of legal obligations. Part III sets out the undertakings that a state must accept to become a contracting party, and Part IV lays down the rules for the regular supervisory machinery that is based on the submission by states parties of periodic reports that are assessed from the point of view of compliance with the standards of the Charter by the European Committee of Social Rights. ${ }^{10}$ Parts V and VI (VI only in the Revised ESC) contain ancillary provisions of various kinds. Finally, each instrument has an Appendix, which forms 'an integral part', containing a series of clauses interpreting or adding to different provisions of the 1961 Charter and the 1996 Revised Charter. ${ }^{11}$

The rights of persons with disabilities are protected under numerous provisions of both the 1961 and 1996 European Social Charter. All the articles guarantee different social rights to all nationals of the contracting parties and foreigners in so far as they are nationals of other Parties' and 'are lawfully resident or regularly working within the territory of the Party concerned. ${ }^{12}$ These include both fully-abled and disabled persons. Articles 1-4 of both Charters (hereinafter also referred to as ESCs) guarantee the rights of employees to work, to just conditions of work, to safe and healthy working conditions, and to fair remuneration. ESC Articles 5-6 guarantee the collective rights of employees: the right to organise and the right to bargain collectively. Subsequent provisions of the Charters (Articles 7-31) regulate other rights, such as the right to vocational guidance, the right to social security, or the right to benefit from social welfare services.

Apart from all the provisions of Part II of the ESC that are applicable to everyone, meaning both fully-abled and disabled persons, there are two provisions that must be especially considered while addressing the issue of the protection of rights of people with disabilities under the 1961 and 1996 Charters-these are Article 15

9 Only Liechtenstein, Monaco, San Marino and Switzerland have not ratified either of these treaties.

10 For more information on the system of supervision of the European Social Charter see: Brillat, R., The supervisory machinery of the European Social Charter: recent developments and their impact, in: De Búrca, G. and De Witte, B. (eds.), Social rights in Europe, Oxford Scholarship Online 2012.

11 See more: Stein E., op. cit, pp. 55-64.

12 ESC/RevESC, Appendix, item 1. 
ESC and Article E of the Revised ESC. Article 15 ESC guarantees people with disabilities the right to independence, social integration, and participation in the life of the community, and Article E Revised ESC expresses the right to equal enjoyment of the rights set forth in the Charter without discrimination on any grounds, such as disability. The prohibition of discrimination (Article E) covers direct and indirect discrimination. Prohibition of indirect discrimination 'calls for contextual intervention to correct the situation. ${ }^{13}$ Inequality is reduced by equalling opportunities by means of positive action favouring disadvantaged persons. The measures may include quotas, priority status in access to goods and services, and the obligation to introduce facilities supporting people with disabilities with independent living.

\section{The right to independence, social integration, and participation in the life of the community}

\section{The content of Article 15 Revised European Social Charter}

The right of persons with disabilities to independence, social integration, and participation in the life of the community is listed in Part I, point 15 of the Revised European Social Charter, and regulated in detail in Part II, Article 15. ${ }^{14}$

Pursuant to Article 15 ESC, 'with a view to ensuring to persons with disabilities, irrespective of age and the nature and origin of their disabilities, the effective exercise of the right to independence, social integration, and participation in the life of the community, the Parties undertake, in particular:

- to take the necessary measures to provide persons with disabilities with guidance, education and vocational training in the framework of general schemes wherever possible or, where this is not possible, through specialised bodies, public or private (par. 1);

- to promote their access to employment through all measures tending to encourage employers to hire and keep in employment persons with disabilities in the ordinary working environment and to adjust the working conditions to the needs of the disabled or, where this is not possible by reason of the disability, by arranging for or creating sheltered employment according to the level of disability. In certain cases, such measures may require recourse to specialised placement and support services (par. 2);

13 Mikkola, M., Social human rights of Europe, Karelactio 2010, p. 554.

14 For the interpretation of Article 15 ESC 1961 see: Samuel, L., Fundamental social rights. Case law of the European Social Charter, second edition, Strasbourg 2002. 
- to promote their full social integration and participation in the life of the community in particular through measures, including technical aids, aiming to overcome barriers to communication and mobility, and enabling access to transport, housing, cultural activities, and leisure (par. 3)'.

The protection afforded by Article 15 of the Revised ESC has been extended compared to that afforded by Article 15 of the 1961 Charter, as it no longer applies only to vocational training, rehabilitation, and social resettlement ${ }^{15}$ but also to independent social integration, personal autonomy, and participation in the life of the community in general. The words 'effective exercise of the right to independence' contained in the introductory sentence to the provision imply, inter alia, that disabled persons should have the right to an independent life. ${ }^{16}$

Article 15 ESC reflects and advances the change in disability policy away from segregation and treating disabled persons as objects of pity and towards inclusion, choice, and respecting people with disabilities as equal citizens - an approach that the Council of Europe contributed to promote, with the adoption by the Committee of Ministers of Recommendation (92)6 of 1992 on a coherent policy for people with disabilities. The underlying vision of Article 15 ESC is one of equal citizenship for persons with disabilities and, fittingly, the primary rights are those of independence, social integration, and participation in the life of the community. ${ }^{17}$ In light of this, the non-discrimination norm has a very important role in the disability context and forms an integral part of Article 15 of the Charter. ${ }^{18}$

Under Article 15 ESC, states must aim to develop a coherent policy for people with disabilities. The provision takes a modern approach to how the protection of the disabled should be carried out, for example, by stipulating that guidance, education, and vocational training be provided whenever possible in the framework of general schemes rather than in specialised institutions, an approach that corresponds to that of Recommendation No. R (92) 6 of the Committee of Ministers of the Council of Europe. It not only provides the possibility, but to a large extent

15 On the protection afforded by the 1961 European Social Charter see more: Schömann, I., Article 15 The Right of Disabled Persons to Vocational Training, rehabilitation and Resettlement, in: Bruun, N. et al. (eds), The European Social Charter and the employment relation, Oxford and Portland 2017.

16 CoE, Explanatory Report to the European Social Charter (Revised), Strasbourg, 3.05.1996, ETS No. 163, p. 63.

17 ECSR, Association internationale Autisme-Europe (AIAE) v. France, Complaint No. 13/2002, Decision on the merits of 4 November 2003 (hereinafter Complaint No. 13/2002), $₫ 48$; Conclusions 2003, Statement on Interpretation on Article 15; CoE, The digest of the case law of the European Committee of Social Rights, December 2018, (hereinafter referred to as: Digest 2018), p. 157, https:// rm.coe.int/digest-2018-parts-i-ii-iii-iv-en/1680939f80 (accessed 15.02.2020). 
obliges the parties to adopt positive measures for the disabled. ${ }^{19}$ Equality of treatment is required to exist not only in law but also in practice. ${ }^{20}$

The right to independence, social integration, and participation in the life of the community guaranteed under Article 15 ESC consists of three main components supporting people with disabilities in three main areas of life, these being: the right to guidance, education, and vocational training (par. 1); the right to equal access to employment (par. 2), and the right to full social integration and participation in the life of the community (par. 3). Combined with the definition of disability, these three components determine the scope of support provided to people with disability under the Charter in practice.

\section{Definition of disability}

Article 15 ESC applies to all persons with disabilities regardless of the nature and origin of their disability and irrespective of age. In the regulations of the Council of Europe, there is no legal definition of 'disability'; 'person/people with a disability' or 'discrimination on the basis of disability'. In its decisions and conclusions, ${ }^{21}$ the European Committee of Social Rights 22 turns directly to the definition of 'disability' and 'person/people with a disability' endorsed by the WHO in its International Classification of Functioning, Disability, and Health ${ }^{23}$ ('ICF') and to the definition of 'discrimination on the basis of disability' used in the United Nations Convention on the Rights of Persons with Disabilities ('CRPD') ${ }^{24}$ based on the ICF model. ${ }^{25}$

The first document, known more commonly as the ICF, is a classification of health and health-related domains and is the WHO framework for measuring health and disability at both the individual and population levels. The ICF was officially endorsed by all 191 WHO Member States in the 54th World Health Assembly

19 CoE, Explanatory Report ..., p. 64.

20 CoE, ESC/RevESC Appendix, item 1; Complaint No. 13/2002, § 48; Conclusions XIV-2 (1998), Statement of Interpretation on Article 15; Digest 2018, p. 157.

21 ECSR, Conclusions 2016, Hungary, Article 15.1.

22 On the impact of the jurisprudence of the ECSR see: Akandji-Kombé, J.F., The material impact of the jurisprudence of the European Committee of Social Rights, in: de Búrca, G. et al. (eds), Social rights in Europe, Oxford Scholarship Online 2012.

23 WHO, International Classification of Functioning, Disability and Health (ICF), 22.05.2011, WHA54.21, https://www.who.int/classifications/icf/en/ (accessed 26.02.2020).

24 ECSR, Mental Disability Advocacy Centre (MDAC) v. Belgium, Complaint No. 109/2014 (hereinafter Complaint No. 109/2014), Decision on the merits of 16 October 2017, $\$ \$ 22-24$.

25 See more: Cera, R., Article 2 [Definitions], in: Della Fina, V. et al. (eds), The United Nations Convention on the Rights of Persons with Disabilities, New York 2017, pp. 107-118. 
on 22 May $2001^{26}$ as the international standard to describe and measure health and disability.

Before the ICF, two major conceptual models of disability had been proposed. The medical model views disability as a feature of a person directly caused by disease, trauma, or other health condition that requires medical care provided in the form of individual treatment by professionals. Disability, in this model, calls for medical or other treatment or intervention, to 'correct' the problem with the individual.

The social model of disability, on the other hand, sees disability as a socially created problem and not at all an attribute of an individual. In the social model, disability demands a political response, since the problem is created by an unaccommodating physical environment brought about by attitudes and other features of the social environment.

The idea of the ICF is that on their own, neither model is adequate, although both are partially valid. Disability is a complex phenomenon that is at one and the same time a problem at the level of a person's body and a complex and primarily social phenomena. Disability is always an interaction between features of the person and features of the overall context in which the person lives. Some aspects of disability are almost entirely internal to the person, while others are almost entirely external. In other words, both medical and social responses are appropriate to the problems associated with disability; we cannot wholly reject either kind of intervention. A better model of disability, in short, is one that synthesises what is true in the medical and social models, without making the mistakes inherent in each one in reducing the whole, complex notion of disability to one of its aspects. This more useful model of disability might be called the 'biopsychosocial model' or 'the human rights model. ${ }^{27}$ The ICF is based on this model and provides a coherent view of different perspectives of health-biological, individual, and social. ${ }^{28}$

Pursuant to Article 2 CRPD, 'discrimination on the basis of disability' means any distinction, exclusion or restriction on the basis of disability which has the purpose or effect of impairing or nullifying the recognition, enjoyment or exercise, on an equal basis with others, of all human rights and fundamental freedoms in the political, economic, social, cultural, civil or any other field. It includes all forms

26 WHO, op. cit.

27 Degener, T.A., A new human rights model of disability, in: Della Fina, V. et al. (eds), The United Nations Convention on the Rights of Persons with Disabilities, New York 2017, pp. 41-59 and Degener, T., Disability in a human rights context, "Laws" 2016, Vol. 5, Issue 3, https://www.mdpi. com/2075-471X/5/3/35/htm (accessed 27.10.2020).

28 WHO, Towards a common language for functioning, disability and health: ICF, Geneva 2002, WHO/ EIP/GPE/CAS/01.3, pp. 8-9, https://www.who.int/classifications/icf/icfbeginnersguide.pdf?ua=1 (accessed 28.02.2020). 
of discrimination, including denial of reasonable accommodation. 'Reasonable accommodation' means necessary and appropriate modification and adjustments not imposing a disproportionate or undue burden, where needed in a particular case, to ensure to persons with disabilities the enjoyment or exercise on an equal basis with others of all human rights and fundamental freedoms.

While assessing state legislation under Article 15 ESC, the European Committee on Social Rights finds incompatibility in the definitions of disability with the ESC where the definitions of disability and persons with disabilities focus on impairments of an individual rather than on the barriers that he/she faces, as such definitions fail to encompass all persons with disabilities, including those with psychosocial disabilities. ${ }^{29}$

\section{The right to guidance, education, and vocational training}

Securing the right to education for children, adolescents, and adults with disabilities plays an important role in advancing their citizenship rights and guaranteeing their fundamental rights, ${ }^{30}$ as education and training are essential foundations to obtain a position in the open labour market and to be able to lead a self-determined life. ${ }^{31}$ The rights to vocational guidance and training are generally laid down in Articles 1.4, 9 and 10 ESC, and Article 15.1 ESC refers specifically to persons with disabilities, aiming at offering increased protection in the areas where people with disabilities are one of the most vulnerable groups.

Pursuant to Article 15.1 ESC, all persons with disabilities-children, adolescents, and adults who face particular disadvantages in education, including persons with intellectual disabilities-have the right to education and training. This right encompasses all levels of education, starting with primary education, through general and vocational secondary education, as well as other forms of vocational training, and finishing with all types of higher education, including at the university level. ${ }^{32}$

Education provided to people with disabilities must be inclusive. Inclusiveness requires free and unlimited accessibility of educational premises both in legal and practical terms. Pursuant to Article 15.1 ESC, education must be ensured within the framework of general schemes wherever possible or, where this is not possible,

29 ECSR, Conclusions 2016, Hungary, Article 15.1.

30 Complaint No. 13/2002, \$ 48; Digest 2018, p. 157.

31 ECSR, Conclusions XX-1 (2012), Austria; Digest 2018, p. 158.

32 ECSR, Conclusions 2012, Ireland; Digest 2018, p. 157. 
through specialised bodies, public or private. This formulation of Article 15.1 of the Charter does not leave states a wide margin of options when it comes to choosing the type of school in which they will promote the independence, integration, and participation of persons with disabilities, as the priority is given to education in mainstream establishments whenever possible. ${ }^{33}$ Specialised institutions should be education providers only in those situations where the type of disability, its severity or a variety of individual circumstances make mainstream education impossible or especially ineffective, which must be examined on a case-by-case basis ${ }^{34}$. In such cases, specialised institutions must ensure through their internal organisation and working methods the predominance of guidance, education, and vocational training over the other functions and duties that they may be required to perform under domestic law ${ }^{35}$.

Both types of schools must guarantee equal and non-discriminatory treatment to persons with disabilities, which means they must ensure physical accessibility of buildings and classes, ${ }^{36}$ adequate lessons, ${ }^{37}$ adapted teaching, ${ }^{38}$ and human assistance for the person's school career where needed (e.g., for children and adolescents with autism in mainstream schools). ${ }^{39}$ The room to manoeuvre in these matters applies only to the means that states deem most appropriate, bearing in mind the cultural, political, or financial circumstances in which their education systems operate. However, the choices made and the means adopted cannot be of a nature or applied in a way that deprives the established right of its effectiveness and turns it into a purely theoretical right. ${ }^{40}$

Under Article 15.1 ESC, the existence of non-discrimination legislation is considered necessary as an important tool for the advancement of the inclusion of children with disabilities into general or mainstream educational schemes. Such legislation should, at a minimum, require a compelling justification for special or segregated educational systems and confer an effective remedy on those who are found to have been unlawfully excluded or segregated or otherwise denied an

33 ECSR, European Action of the Disabled (AEH) v. France, Complaint No. 81/2012 (hereinafter Complaint No. 81/2012), Decision on the merits of 11 September 2013, $\$ 78$; Digest 2018, p. 158.

34 Digest 2018, p. 158.

35 Complaint No. 81/2012, Decision on the merits of 11 September 2013, § 111; Digest 2018, p. 158.

36 ECSR, Conclusions 2005, Cyprus.

37 Complaint No. 13/2002, $\$ 48$.

38 Complaint No. 81/2012, Decision on the merits of 11 September 2013, $\$ 85$.

39 Ibidem, $\$ 85$.

40 Ibidem, $\$ \$ 80-81$; Digest 2018, p. 158. 
effective right to education. Legislation may consist of general anti-discrimination legislation, specific legislation concerning education, or a combination of the two. ${ }^{41}$

The European Committee of Social Rights found violations of Article 15.1 ESC in cases where there existed a lack of effective integration of children and youth with disabilities into mainstream education and into mainstream vocational training facilities, and so special and separate facilities remained the norm, ${ }^{42}$ or where the minority ${ }^{43}$ or almost half of pupils with special educational needs attended special schools. ${ }^{44}$ Non-compliance with Article 15.1 ESC $^{45}$ was also declared by the ECSR in cases where there was found to be a lack of equal access of children with disabilities to education, where many children with disabilities were placed in institutions, particularly those with mental disabilities (who accounted for about $80 \%$ of all children living in institutions), and did not therefore have equal access to education. ${ }^{46}$

\section{The right to equal access to employment}

Securing the right to equal access to employment for people with disabilities plays an important role in advancing their citizenship rights and guaranteeing their fundamental rights by obtaining a position in the open or specialised labour market, which enables them to lead a self-determined life. The rights to work, just conditions of work, and safe and healthy conditions at work, are generally laid down in Articles 1, 2, and 3 ESC, and Article 15.2 ESC refers specifically to persons with disabilities, aiming at offering increased protection in the area of employment where people with disabilities are more vulnerable than other employees.

Pursuant to Article 15.2 ESC, all persons with disabilities, both physically and intellectually disabled, ${ }^{47}$ have the right to equal access to employment. Under this article, states are required to promote their access to employment through all

41 ECSR, Conclusions 2007, Statement of interpretation on Article 15.1.

42 ECSR, Conclusions XVI-2 (2004), Malta, Article 15.1.

43 ECSR, Conclusions 2016, Ukraine, Article 15.1.

44 ECSR, Conclusions 2016, Austria, Article 15.1, Conclusions 2016, Romania, Article 15.1.

45 For assessment of Ukrainian legislation see: Smusz-Kulesza, M., Report on the needs assessment in respect of social rights in Ukraine conducted within the framework of the Council of Europe project "Framing cooperation for social rights development in Ukraine', Council of Europe 2019, available at: https://rm.coe.int/report-on-the-needs-assessment-in-respect-of-social-rights-in-ukraine-/168093d9a2 (accessed 19.10.2020).

46 ECSR, Conclusions 2016, Serbia, Article 15.1.

47 ECSR, Conclusions XX-1 (2012), Czech Republic; Conclusions I (1969), Statement of Interpretation on Article 15.2. 
measures, to encourage employers to hire and keep in employment persons with disabilities in the ordinary working environment and to adjust the working conditions to the needs of the disabled or, where this is not possible by reason of the disability, by arranging for or creating sheltered employment according to the level of disability. In certain cases, such measures may require recourse to specialised placement and support services.

In accordance with Article 15.2 ESC, access to employment must be ensured within the framework of the open labour market wherever possible or, where this is not possible, through sheltered employment, public or private. Such formulation of Article 15.2 of the Charter does not leave states a wide margin of options when it comes to choosing the type of employment in which they will promote the equality of persons with disabilities, as the priority is given to the open labour market whenever possible. Sheltered employment, understood as covering also working co-operatives, ${ }^{48}$ should be provided only in situations where the type of disability, its severity, or a variety of individual circumstances make integration into the open labour market impossible or especially ineffective, which must be examined on a case-by-case basis. In such cases, persons working in sheltered employment facilities must be entitled to the basic provisions of labour law and in particular the right to fair remuneration and trade union rights. ${ }^{49}$ Sheltered employment facilities, apart from providing work, should aim to assist their beneficiaries to enter the open labour market. ${ }^{50}$

Access to employment provided to people with disabilities must be equal. To this aim, discrimination on the basis of disability in employment (including the conditions of dismissal) must be prohibited. ${ }^{51}$ In addition, regarding work conditions, 'there must be obligations on the employer to take steps in accordance with the requirement of reasonable accommodation to ensure effective access to employment and to keep in employment persons with disabilities, in particular persons who have become disabled while in their employment as a result of an industrial accident or occupational disease. ${ }^{52}$ Apart from that, regulations must 'confer an effective remedy on those who are found to have been unlawfully discriminated. ${ }^{53}$ Apart from the abovementioned obligations, states enjoy a margin of discretion concerning other measures they take in order to promote access to employment of

\footnotetext{
48 CoE, Explanatory Report ..., p. 65.

49 ECSR, Conclusions XVII-2 (2005), Czech Republic.

50 ECSR, Digest 2018, p. 158.

51 ECSR, Conclusions 2003, Slovenia; Conclusions 2012, Russian Federation.

52 ECSR, Conclusions 2007, Statement of Interpretation on Article 15.2.

53 ECSR, Conclusions XIX-1 (2008), Czech Republic.
} 
persons with disabilities-in particular, Article 15.2 ESC does not require the introduction of a system of quotas. ${ }^{54}$ Under the approach adopted in Article 15.2 ESC, the state is responsible for adopting measures to help disabled persons participate fully and actively in the labour market. Those measures, if needed, may take the form of positive action designed to improve the 'employability' of disabled persons and their access and ability to remain in employment. Particular emphasis must be put on the protection of persons who are disabled as a result of an occupational accident or illness..$^{55}$

The European Committee of Social Rights found violations of Article 15.2 ESC in cases of a lack of legislation prohibiting discrimination on the grounds of disability in the field of employment ${ }^{56}$ or lack of adequate protection against discrimination on the grounds of disability - a lack of measures protecting employees with disabilities from dismissal and lack of an obligation for employers to continue to employ a person who becomes disabled following an occupational injury or disease. ${ }^{57}$ Apart from that, non-compliance with Article 15.2 ESC was established in cases of excessively low wage levels in sheltered employment facilities where persons employed performing production-orientated work were not subject to the usual terms and conditions of employment and their pay was much lower than that in the open working environment (varying between 5\% and 30\%). ${ }^{58}$

\section{The right to full social integration and participation in the life of the community}

Securing the right to full social integration and participation in the life of the community for people with disabilities is the essence of guaranteeing their fundamental rights. The rights to protection of health, social and medical assistance, social welfare services, and housing are generally laid down in Arts. 11, 13, 14, 31 ESC, and Article 15.3 ESC refers specifically to persons with disabilities, aiming at offering increased protection in the area of community life where people with disabilities are more vulnerable than other members of the society.

Pursuant to Article 15.3 ESC, all persons with disabilities have the right to full social integration and participation in the life of the community, which should

54 ECSR, Conclusions XIV-2 (1998), Belgium.

55 ECSR, Conclusions XIV-2, Statement of interpretation on Article 15.

56 ECSR, Conclusions XVI-2 (2004), Belgium, Article 15.2; Conclusions XVI-2 (2004), Spain, Article 15.2.

57 ECSR, Conclusions XVI-2 (2004), Denmark, Article 15.2.

58 Ibidem. 
be promoted in particular through measures, including technical aids, aiming to overcome barriers to communication and mobility and 'enable access to transport (land, rail, sea and air), housing (public, social and private), cultural activities and leisure (social and sporting activities)' ${ }^{59}$ To this end, Article 15.3 ESC 'requires the existence of comprehensive non-discrimination legislation covering both the public and private sphere in fields such as housing, transport, telecommunications and cultural and leisure activities and effective remedies for those who have been unlawfully treated. ${ }^{60}$ Such legislation may consist of general anti-discrimination legislation, specific legislation, or a combination of the two. ${ }^{61}$

Article 15.3 ESC requires the 'adoption of a coherent policy in the disability context: positive action measures to achieve the goals of social integration and full participation of persons with disabilities. Such measures should have a clear legal basis and be coordinated.' ${ }^{62}$ People with disabilities should have a voice in the design, implementation, and review of policies concerning them. ${ }^{63}$ To achieve the aim of Article 15.3 ESC, mechanisms must be established to assess the barriers to communication and mobility faced by persons with disabilities and identify the support measures that are required to assist them in overcoming these barriers. ${ }^{64}$

Furthermore, technical aids must be available, either for free or subject to a contribution towards their cost and taking into account the beneficiary's means. Such aids may, for example, take the form of prostheses, walkers, wheelchairs, guide dogs, appropriate housing support arrangements, or support services such as personal assistance and auxiliary aids. ${ }^{65}$

To achieve full social integration and participation of people with disabilities in the life of the community, 'telecommunications and new information technology must be accessible and sign language must have an official status. ${ }^{66}$ 'Public transports (land, rail, sea and air), all newly constructed or renovated public buildings, facilities and buildings open to the public, and cultural and leisure activities should be physically accessible. ${ }^{67}$

\footnotetext{
59 ECSR, Conclusions 2005, Norway.

60 ECSR, Conclusions 2007, Slovenia.

61 ECSR, Conclusions 2012, Estonia.

62 Digest 2018, p. 161.

63 ECSR, Conclusions 2003, Italy.

64 ECSR, Conclusions 2008, Statement of interpretation on Article $15 \S 3$; Digest 2018, pp. 161-162.

65 Digest 2018, pp. 161-162.

66 ECSR, Conclusions 2005, Estonia; Conclusions 2003, Slovenia.

67 ECSR, Conclusions 2003, Italy; Digest 2018, pp. 161-162.
} 
'The needs of persons with disabilities must be taken into account in housing policies, including the construction of an adequate supply of suitable, public, social or private, housing. Further, financial assistance should be provided for the adaptation of existing housing. ${ }^{6} 8$

The European Committee of Social Rights found violations of Article 15.3 ESC in cases where there was a lack of anti-discrimination legislation for persons with disabilities that specifically cover the areas of housing, transport, communications, culture, and leisure. ${ }^{69}$

\section{Conclusions}

The rights of persons with disabilities are protected under numerous provisions of the 1961 and 1996 European Social Charter. Protection conferred by the 1996 ESC is wider than that conferred by the earlier version as the latter is a revised and extended version. All the articles of both the 1961 and 1996 Charter guarantee different social rights to all-fully-abled and disabled persons. Additionally, the 1996 European Social Charter in Article E directly states that the enjoyment of the rights set forth in the Charter shall be secured without discrimination on any grounds, such as e.g. disability.

Apart from these, Article 15 of the 1961 and 1996 ESC guarantee people with disabilities special protection. Article 151996 ESC establishes the right to independence, social integration, and participation in the life of the community. The aim of Article 15 ESC is to offer increased protection in areas of life where people with disabilities are most vulnerable-education, guidance, vocational training, employment, and community life. While assessing the compliance of state regulations with Article 15 ESC, the European Committee of Social Rights highlights the importance of inclusiveness as an essential characteristic of all the above-mentioned areas. 'Integration' and 'inclusion' are two different notions and one does not necessarily lead to the other. The right to inclusive education, guidance, vocational training, employment, and community life is about the person's right to participate in the mainstream institutions of these fields and the institutions' obligation to accept the person, taking into account the best interests of the person as well as their abilities and needs as the primary consideration. ${ }^{70}$

68 Digest 2018, pp. 161-162.

69 ECSR, Conclusions 2016, Estonia, Article 15.3.

70 Complaint No. 109/2014, Decision on the merits of 16 October 2017, $₫ 66$; Digest 2018, p. 158. 
The European Committee of Social Rights found incompatibility of different states' provisions with Article 15 ESC in cases of definitions of disability focusing on impairments of an individual rather than on the barriers that disabled people face; in cases of lack of equal access of children with disabilities to education and in cases of lack of effective integration of children and youth with disabilities into mainstream education vocational training. Non-compliance with Article 15.1-3 ESC was also declared by the ECSR in cases of lack of effective legislation prohibiting discrimination on the grounds of disability in the field of employment, housing, transport, communications, culture and leisure.

\section{References}

Akandji-Kombé, J.F., The material impact of the jurisprudence of the European Committee of Social Rights, in: de Búrca, G. et al. (eds), Social rights in Europe, Oxford Scholarship Online 2012.

Brillat, R., The supervisory machinery of the European Social Charter: recent developments and their impact, in: De Búrca, G. and De Witte, B. (eds.), Social rights in Europe, Oxford Scholarship Online 2012.

Cera, R., Article 2 [Definitions], in: Della Fina, V. Et al. (eds), The United Nations Convention on the Rights of Persons with Disabilities, New York 2017.

CoE, Explanatory report to the European Social Charter (Revised), Strasbourg, 3.V.1996, ETS No. 163.

Degener, T., A new human rights model of disability, in: Della Fina, V. et al. (eds), The United Nations Convention on the Rights of Persons with Disabilities, New York 2017.

Degener, T., Disability in a human rights context, "Laws" 2016, Vol. 5, Issue 3, https:// www.mdpi.com/2075-471X/5/3/35/htm.

De Schutter O. (ed.), The European Social Charter: a social constitution for Europe, Bruylant 2010.

ECSR, The digest of the case law of the European Committee of Social Rights, December 2018, https://rm.coe.int/digest-2018-parts-i-ii-iii-iv-en/1680939f80.

Evju, S., The European Social Charter-instruments and procedures, "Nordic Journal of Human Rights"2007, Vol. 25, No. 1.

Harris, D., The European Social Charter, "International and Comparative Law Quarterly" 1964, Vol. 13.

Harris, D. and D'Arcy, J., The European Social Charter, 2nd edition, Ardsley 2001.

O'Cinneide, C., The European Social Charter and the UK: why it matters, "King's Law Journal" 2018, Vol. 29, No. 2.

Mikkola, M., Social human rights of Europe, Karelactio 2010. 
Samuel, L., Fundamental social rights. Case law of the European Social Charter, second edition, Strasbourg 2002.

Schömann, I., Article 15 The Right of Disabled Persons to Vocational Training, Rehabilitation and Resettlement, in: Bruun, N. et al. (eds.), The European Social Charter and the employment relation, Oxford and Portland 2017.

Smusz-Kulesza M., Report on the needs assessment in respect of social rights in Ukraine conducted within the framework of the Council of Europe Project 'Framing cooperation for social rights development in Ukraine, Council of Europe 2019, https:// $\mathrm{rm}$.coe.int/report-on-the-needs-assessment-in-respect-of-social-rights-in-ukraine/168093d9a2.

Stein, E., The European Social Charter-instruments and procedures, "Nordic Journal of Human Rights", Vol. 25, No. 1, 2007.

Valticos, N., La Charte sociale européenne: sa structure, son contenu, le contrôle de son application, "Droit Social” 1963, Vol. 26.

Wiebringhaus, H., La Charte sociale européenne, "Annuaire Français de Droit International" 1963, Vol. 9.

WHO, Towards a common language for functioning, disability and health: ICF, Geneva 2002, WHO/EIP/GPE/CAS/01.3.

WHO, International Classification of Functioning, Disability and Health (ICF), 22.05.2011, WHA54.21, https://www.who.int/classifications/icf/en/.

\section{CITATION}

Smusz-Kulesza, M., Protection of the rights of persons with disabilities under the European Social Charter, “Acta Iuris Stetinensis" 2020, No. 3 (Vol. 31), 107-122, DOI: 10.18276/ais.2020.31-07. 